\title{
Study of interaction between chitosan and active carbon in view of optimising composite gels devoted to heal injuries
}

\author{
N. Mnasri ${ }^{1,4, a}$, Y. Moussaoui ${ }^{2}$, E. Elaloui ${ }^{1}$, R. ben Salem ${ }^{2}$, S. Lagerge ${ }^{3}$, J. M. Douillard ${ }^{4}$ and L. C. de \\ Menorval $^{4}$ \\ ${ }^{1}$ Material Environment and Energy Laboratory, Science Faculty of Gafsa, 2112, Gafsa University, \\ Gafsa, Tunisia. \\ ${ }^{2}$ Physical Organic Chemistry Laboratory, Science Faculty of Sfax, 3018, Sfax University, Sfax, \\ Tunisia. \\ ${ }^{3}$ E M I, UMR 5635 CNRS, ENSCM, UM2, University of Montpellier 2, CC 047, Place Eugéne
} Bataillon, 34095 Montpellier Cedex 5, France

${ }^{4}$ AIME, ICGM, UMR 5253, University of Montpellier 2, CC 1500, Place Eugène Bataillon, 34095 Montpellier Cedex 5 - France

\begin{abstract}
In order to develop biomaterials useful in reconstructive surgery, mechanism of adsorption of chitosan onto activated carbon has been investigated. Activated carbons have been characterised using $\mathrm{SEM}, \mathrm{NH}_{3}$ adsorption and ${ }^{129} \mathrm{Xe}$ NMR spectroscopy. Adsorption of chitosan on activated carbon in acid aqueous solution increases when the degree of acetylation of chitosan decreases. Sterilization does not modify the adsorption capacity of the studied sample of activated carbon.
\end{abstract}

\section{Introduction}

Chitosan has many interesting properties related of biocompatibility and bioactivity. It is not toxic and it is biodegradable, bioactive [1-3] and can be used for muco-adhesion or biofilm formation. This allows biomedical, pharmaceutical and clinical applications [4-12] and such use of chitosan is currently receiving a great deal of attention [13-18]. Chitosan will be used in medicine, particularly in reconstructive surgery. It accelerates wound healing [4,5,7] because it promotes a reduction in collagen synthesis reactions, an increase of the number of histiocytes, a stimulation of fibroblasts that produce collagen-3, essential in the phenomena of healing $[19,20]$. Chitosan is one of the few natural cationic polyelectrolytes [21,22]. In acid solution, it behaves as a polycation and the dissolution is related to the interaction between water molecules and protonated amine functions of the macromolecules [23].

With the purpose to build composite materials with chitosan and activated carbons (AC), we have studied adsorption mechanisms of chitosan on some samples, which are approved for medicinal use. The use of active carbon is related here to deodorizing property. We performed the experiments in aqueous phase with two types of chitosan on two types of active carbons approved by the European Pharmacopoeia. We have also studied the influence of sterilization using gamma radiation

\footnotetext{
a e-mail : mnasri.nejib@gmail.com
} 
with one sample. Given the medical application of the particles of AC, the sterilization step is necessary during the manufacturing process of the gel.

\section{Materials and methods}

\subsection{Adsorbent}

The adsorbent used are powdered activated carbon, Norit A SUPRA EUR and Norit B SUPRA EUR EUR, supplied by Norit Nederland BV. These activated carbons meet the requirements of the European Pharmacopoeia.

\subsection{Adsorbate}

Chitosan (see Figure 1) can be characterized by the fraction of $\mathrm{N}$-acetamide groups, i.e. residual degree of acetylation (DA). The adsorbates used were two types of chitosan, denoted batch-112, (DA $\left.=2.9 \%, \mathrm{Mw}=451.10^{3} \mathrm{~g} \cdot \mathrm{mol}^{-1}\right)$ and batch-111 $\left(\mathrm{DA}=13 \%, \mathrm{Mw}=520 \cdot 10^{3} \mathrm{~g} \cdot \mathrm{mol}^{-1}\right)$. They were purchased from Sigma-Aldrich.

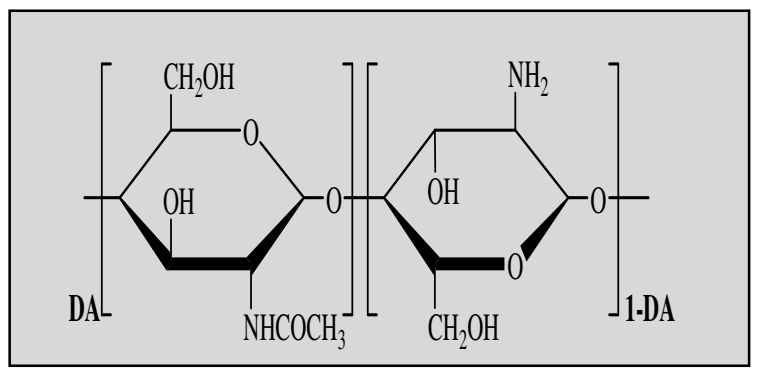

Fig. 1. Chemical structure of chitosan

\subsection{Characterization}

\subsubsection{Adsorption-desorption isotherms}

Measurements are performed using a Micrometrics equipment ASAP 2020. We use N2 at the temperature of $77 \mathrm{~K}$. Before adsorption, all samples were degassed in vacuum at $250^{\circ} \mathrm{C}$ during 15 hours. This technique of gas adsorption gives access to the specific surface $S_{\mathrm{BET}}\left(\mathrm{m}^{2} \cdot \mathrm{g}^{-1}\right)$. Determination of specific area was carried out taking $16.2 \AA^{2}$ as cross sectional area of N2. The porosity has been obtained from B.J.H. equation.

\subsubsection{Scanning electronic microscopy}

The images of SEM were obtained with a Hitachi S-2600N apparatus, using a detector of secondary electrons.

\subsubsection{NMR of Xenon}

Spectra of ${ }^{129}$ Xe NMR were obtained, at $298 \mathrm{~K}$, using a spectrometer BRUKER AC 250L to 69.19 MHz. Before the experiment, the samples were heated under vacuum (10 mbar) to $523 \mathrm{~K}$. 


\subsection{4 $\mathrm{NH}_{3}$ adsorption}

The determination of surface acidity with $\mathrm{NH}_{3}$ was carried out by a two-cycle adsorption procedure at $373 \mathrm{~K}$. The amounts of adsorbed $\mathrm{NH}_{3}$ adsorbed were quantified using a Micromeritics ASAP 2010 Chemi System apparatus.

\subsubsection{Zeta potential}

The zeta potential were recorded on a Zetasizer - Malvern Instruments.

\subsubsection{Adsorption isotherms in aqueous solutions}

The adsorption isotherms of chitosan on activated carbon were performed at ambient temperature in an aqueous solution of acetic acid at $\mathrm{pH}=4$. The concentration of chitosan at equilibrium $\left(\mathrm{C}_{\mathrm{e}}\right)$ is determined by refractometery (cf. E3).

$\mathrm{m}_{1}$ : mass of the solution of chitosan $(\mathrm{kg})$

$$
Q=\left(C_{i}-C_{e}\right) \times m_{1} / m_{2}
$$

$\mathrm{m}_{2:}$ mass of activated carbon in the solution $(\mathrm{kg})$

$\mathrm{C}_{\mathrm{i}}$ : initial concentration of chitosan by weight $\left(\mathrm{mg} \cdot \mathrm{kg}^{-1}\right)$.

$\mathrm{C}_{\mathrm{e}}$ : equilibrium concentration of chitosan by weight $\left(\mathrm{mg} \cdot \mathrm{kg}^{-1}\right)$

The mixtures have been equilibrated overnight before the experiment, under controlled temperature (see below). Acetic acid was supplied by Sigma Aldrich and the water was deionised. The refractometric measurement was recorded with a waters differential Refractometer.

\section{Results and discussion}

\subsection{Characterization of activated carbon}

\subsubsection{Textural analysis}

The porous characteristics obtained from the adsorption-desorption isotherms of nitrogen at $77 \mathrm{~K}$ are listed in Table 1.

Table 1. Specific surface area and pore characteristics of AC samples

\begin{tabular}{|c|c|c|}
\hline & $\begin{array}{c}\text { BET surface } \\
\text { area }\left(\mathbf{m}^{\mathbf{2}} \cdot \mathbf{g}^{-1}\right)\end{array}$ & $\begin{array}{c}\text { Average } \\
\text { pore } \\
\text { diameter } \\
(\AA)\end{array}$ \\
\hline Norit A SUPRA EUR & 1560 & 24 \\
\hline Norit B SUPRA EUR & 1500 & 26 \\
\hline $\begin{array}{c}\text { Norit A SUPRA EUR } \\
\text { sterilized }\end{array}$ & 1610 & 24 \\
\hline
\end{tabular}

The active carbon Norit A SUPRA EUR has both comparable surface area and average pore diameter, than the Norit B SUPRA EUR. The sterilization by gamma radiation does not modify significantly both surface area and porous structure (Table 1). 


\subsubsection{Scanning Electron Microscopy}

The three activated carbons, Norit A SUPRA EUR crude, Norit A SUPRA EUR sterilized and Norit B SUPRA EUR were analyzed by scanning electron microscopy (SEM) and some pictures are listed on Fig.2. The three active carbons have basically the same morphology.

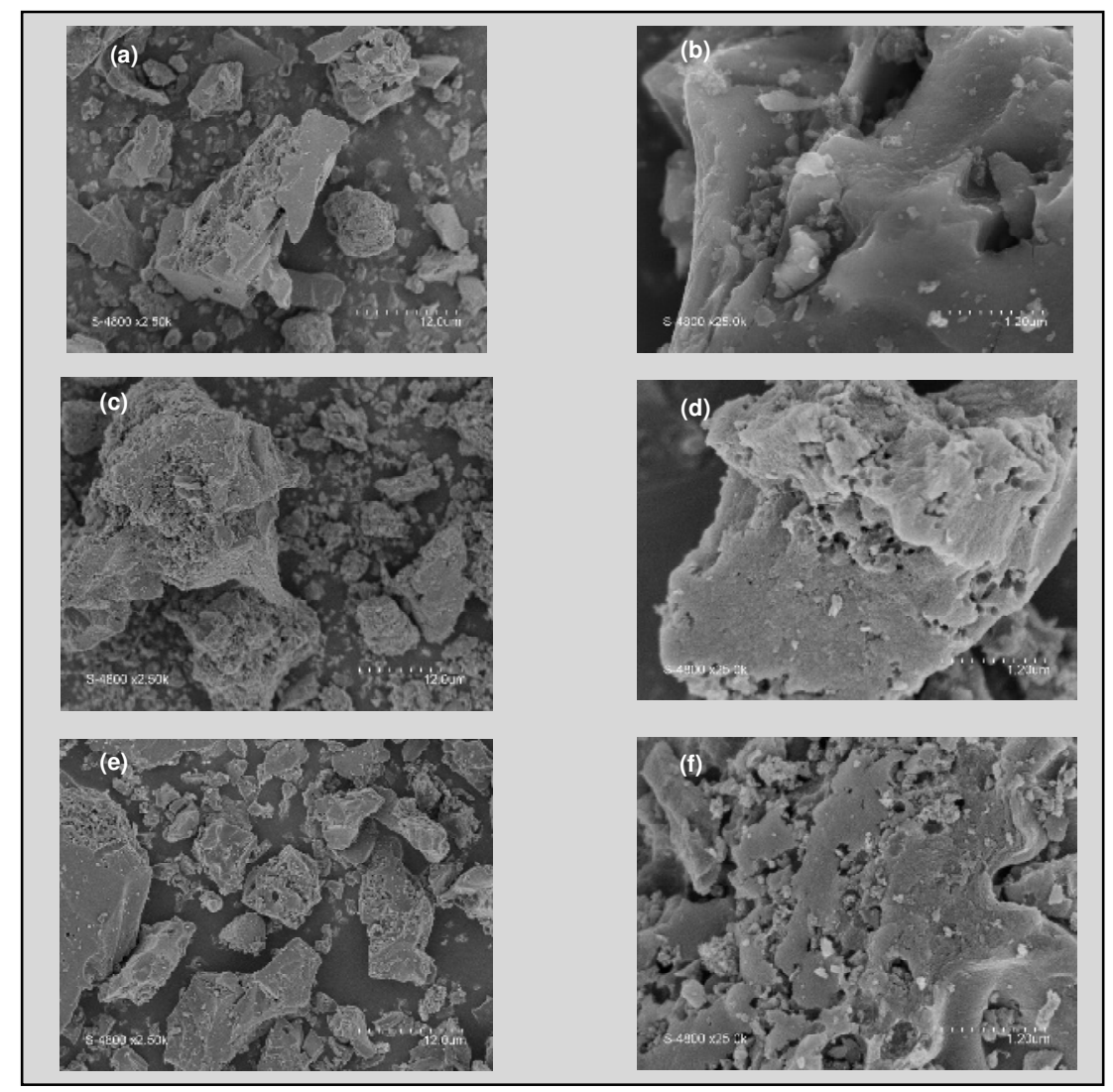

Fig. 2. SEM images of activated carbons: (a) and (b) Norit B SUPRA EUR, (c) and (d) Norit A SUPRA EUR gross, (e) and (f) Norit A SUPRA EUR sterilized

\subsubsection{Determination of the Zeta potential of activated carbons in water}

To analyse the effects of the surface charge and investigate the effect of sterilization by gamma ray, we determined the zeta potential of activated carbons. The results are given in Table 2 .

The zeta potential of Norit A SUPRA EUR is lower than the one of Norit B SUPRA EUR. This is due to the difference in surface composition. The zeta potential of Norit A SUPRA EUR decreases under the effect of sterilization by gamma radiation, indicating that some surface sites have been activated by radiations.

Table 2. Zeta potential in water of activated carbons

\begin{tabular}{|c|c|c|c|}
\hline Carbon & $\begin{array}{c}\text { Norit B } \\
\text { SUPRA EUR }\end{array}$ & $\begin{array}{c}\text { Norit A SUPRA } \\
\text { EUR gross }\end{array}$ & $\begin{array}{c}\text { Norit A SUPRA EUR } \\
\text { sterilized }\end{array}$ \\
\hline$\xi(\mathrm{mV})$ & $-30,40$ & $-39,2$ & -43 \\
\hline
\end{tabular}




\subsubsection{Determination of acid-base properties of surface}

To determine the quantity of acid sites of each activated carbon, we used the two-cycle method [24]. Basically the first cycle gives the total amount adsorbed and the second cycle gives the physically adsorbed amount. By difference, one gets the chemically adsorbed amount. This effect of chemisorptions can be related to a surface density of acidic sites. The results are shown in Figures 3 and 4. To determine the surface density of acid sites, playing a role in physisorption or in chemisorption, we used the following tree equations for the extrapolated value using the linear part:

$$
\begin{aligned}
& N_{\text {wholesites }}=N_{a d s} / S_{s p} \\
& N_{\text {chemsites }}=\Delta N_{a d s} / S_{s p} \\
& N_{\text {physsites }}=N_{\text {wholesites }}-N_{\text {chemsites }}
\end{aligned}
$$

with $N_{a d s}$ : the number of moles of $\mathrm{NH}_{3}$ chemisorbed per unit mass $\left(\mathrm{m}^{3} \cdot \mathrm{g}^{-1}\right)$, during the first experiment (upper curve) and $\Delta N_{a d s}$ the difference of volumes adsorbed between the first and second cycle. The number of molecules is related to the adsorbed volume by the law of perfect gas.
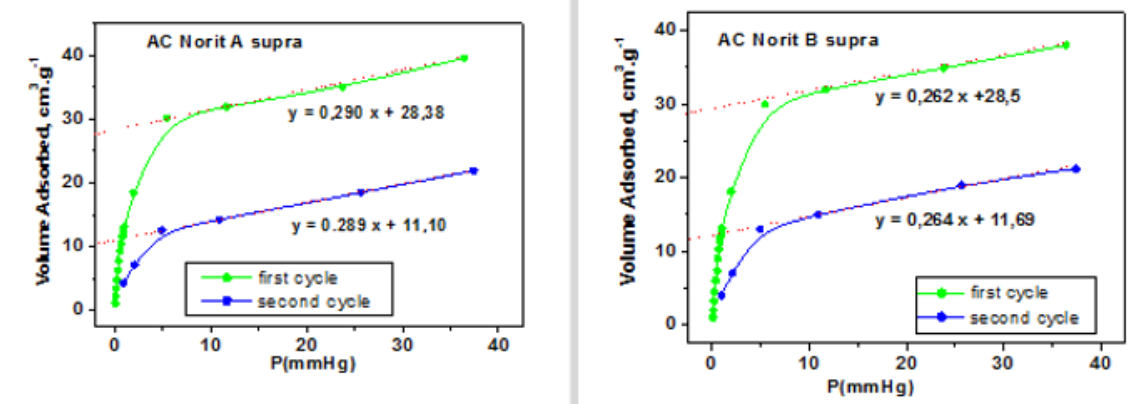

Fig. 3. Profile of two cycles of adsorption of ammonia on Norit A SUPRA EUR and Norit B SUPRA EUR at $\mathrm{T}=303 \mathrm{~K}$.

For both AC Norit A SUPRA EUR and and for AC Norit B SUPRA EUR, the number of acidic sites is 0.3 sites. $\mathrm{nm}^{-2}$. In conclusion the two activated carbons have basically similar acidic surface characteristics.

\subsubsection{Characterization by ${ }^{129} \mathrm{Xe} N M R$}

The different spectra obtained as a function of xenon pressure at room temperature are shown in Figure 4. 


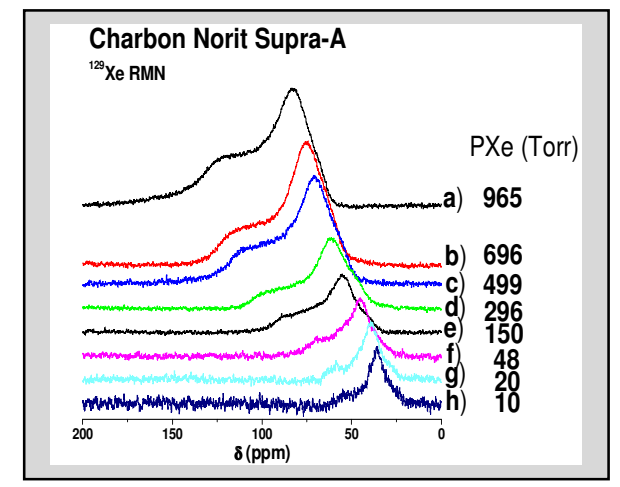

Fig. 4. ${ }^{129} \mathrm{Xe}$ NMR spectrum of activated carbon Norit A SUPRA EUR at room temperature

We observe the existence of two resonances for the ${ }^{129} \mathrm{Xe}$ NMR spectra of activated carbon Norit A SUPRA EUR, whatever the equilibrium pressure of xenon. The observed signals are broad and composed of two main signals, which indicate two types of porosity in the sample.

\subsection{Isothermal adsorption chitosan-activated carbon in aqueous phase at $\mathrm{pH}=4$ (AcOH)}

\subsubsection{Comparison of adsorption capacities of activated carbons}

To compare the adsorption capacities of the two samples (Norit A SUPRA EUR and Norit B SUPRA EUR), we carried out the adsorption of chitosan (batch-112) in acetic acid water solution at $\mathrm{pH}=4$, at $298 \mathrm{~K}$ (Fig.5).

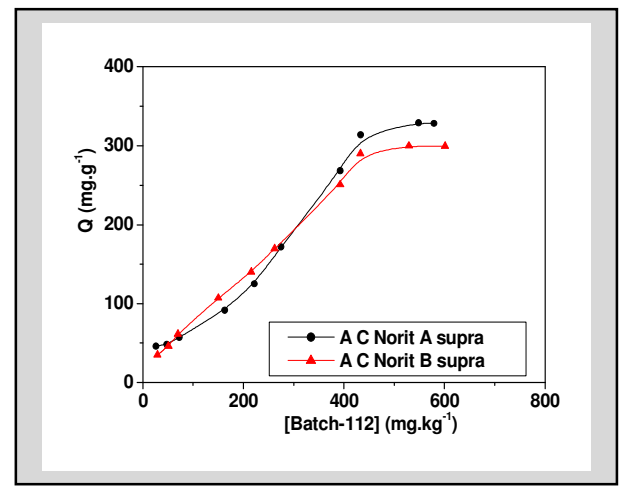

Fig. 5. Adsorption Isotherm of chitosan (batch-112) on the activated carbons; $\mathrm{pH}=4$ and $\mathrm{T}=298 \mathrm{~K}$.

The maximum adsorption capacity of activated charcoal Norit SUPRA EUR A is close to that of activated carbon Norit SUPRA EUR B. This is in agreement with their similar surface areas reported in Table 1.

\subsubsection{Affinity comparison of two batches of chitosan compared to activated carbon}

We also compared the adsorption of two batches of chitosan (batch-111 and batch-112) on the activated carbon Norit A SUPRA EUR, in order to analyse the affinity of chitosan versus activated carbon. 


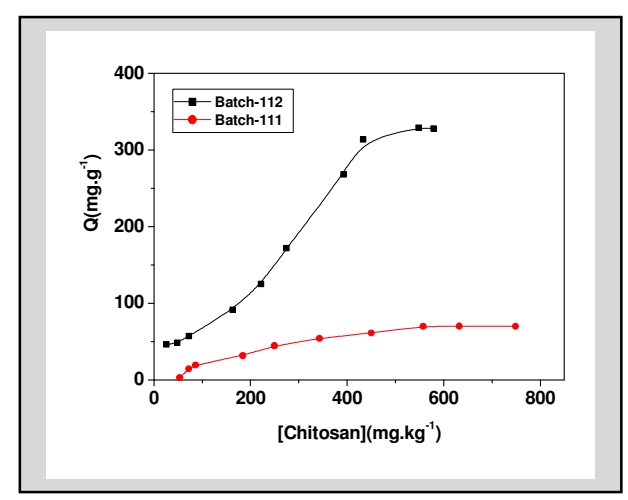

Fig. 6. Isotherm of adsorption of chitosan on the activated carbon in aqueous solution $\mathrm{pH}=4$ at $\mathrm{T}=298 \mathrm{~K}$.

The maximum adsorption of chitosan (batch-112) on activated carbon is $330 \mathrm{mg} \cdot \mathrm{g}^{-1}$, whereas it is 75 mg.g ${ }^{-1}$ for batch-111 (see Fig.6). This is explained by the difference in the acetylation of the two batches of chitosan (2.9\% for batch-112 and $13 \%$ for batch-111). The ratio is about 4.5 . This value is close to the ratio obtained for the maximum adsorption capacity $(330 / 75=4.4)$. The zeta potential of the two activated carbons in acetic acid solution at $\mathrm{pH}=4$ presented above shows that the particle charge is negative. Chitosan which has the lowest DA is the one which has the greatest quantity of surface amine groups $\left(-\mathrm{NH}_{2}\right)$ (see Figure 1). Then, the chitosan batch-112 $(\mathrm{DA}=2.9 \%)$ has a great quantity of amine groups. In the acetic acid solution at $\mathrm{pH}=4$, the amine groups are converted into $\mathrm{NH}_{3}{ }^{+}$. Therefore chitosan batch-112 can generate interaction with the negative sites of the surface of the activated carbon.

\subsubsection{Comparison of adsorption capacities of both activated carbons Norit A SUPRA EUR gross and Norit A SUPRA EUR sterilized}

Since the activated carbon Norit A SUPRA EUR has to be sterilized before use, we studied the influence of this effect on the adsorption of chitosan.

After treatment, the maximum adsorption capacities are very close (Figure 7), which is in good agreement with the basic interpretation of a direct chemical ink between positive groups of chitosan and negative groups of active carbon. As the surface of active carbon seems not to be modified by sterilization, the adsorption remains the same. As pores are narrow, the diffusion of chitosan can become more important, which could explain the small increase of the value at the plateau. 


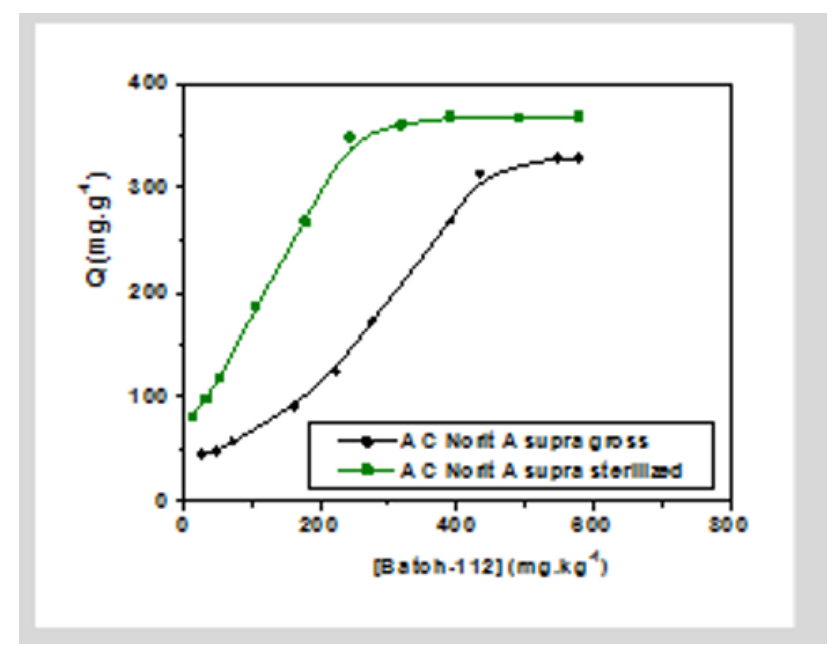

Fig. 7. Adsorption isotherms of chitosan (batch-112) on AC Norit A SUPRA EUR gross and Norit A SUPRA EUR sterilized aqueous solution $\mathrm{pH}=4$ at $\mathrm{T}=298 \mathrm{~K}$

\subsubsection{Effect of temperature on the capacity of chitosan adsorption on activated carbon}

Temperature has a pronounced effect on the adsorption capacity of activated carbons by the chitosan. Figure 8 shows the adsorption isotherms at 298, 308 and $318 \mathrm{~K}$ of the polymer onto activated carbon Norit A SUPRA EUR sterilized.

The adsorption capacity increases with the temperature. This indicates an endothermic adsorption process.

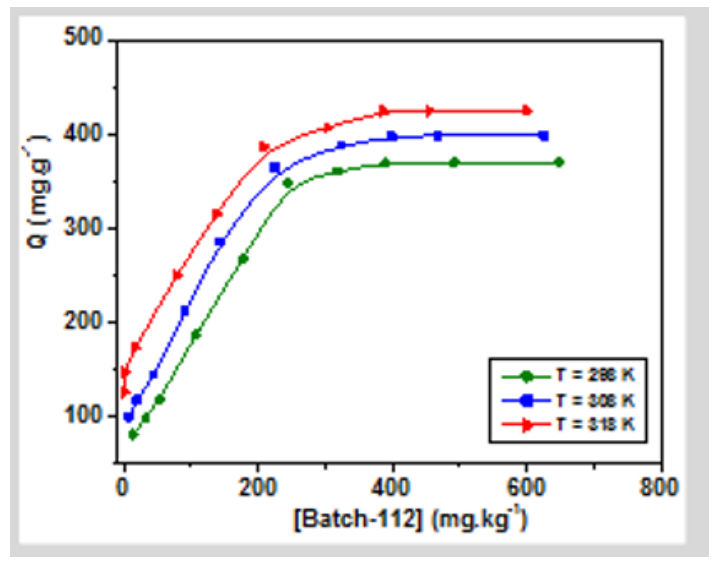

Fig. 8. Adsorption isotherms of chitosan (batch-112) on AC Norit A SUPRA EUR sterilized, at three temperatures.

\subsection{Thermodynamic modelling of adsorption}

The experimental adsorption isotherms were interpreted according to the Langmuir equation. The general form of the Langmuir equation is as follows.

$$
C_{e} / Q=1 / Q K_{L}+C_{e} / Q_{0}
$$


With $\mathrm{C}_{\mathrm{e}}$ : the concentration of adsorbent (polymer) at equilibrium (mg. $\left.\mathrm{kg}^{-1}\right), \mathrm{Q}$ : is the amount of polymer adsorbed $\left(\mathrm{mg} \cdot \mathrm{g}^{-1}\right), \mathrm{K}_{\mathrm{L}}$ : the constant of adsorption $\left(\mathrm{mg}^{\mathrm{kg}} \mathrm{kg}^{-1}\right.$ ) (at a given temperature) related to the energy of sorption, $\mathrm{Q}_{0}$ : the maximum adsorption capacity (mg. $\mathrm{g}^{-1}$ ). (Fig.9 and Table 3).

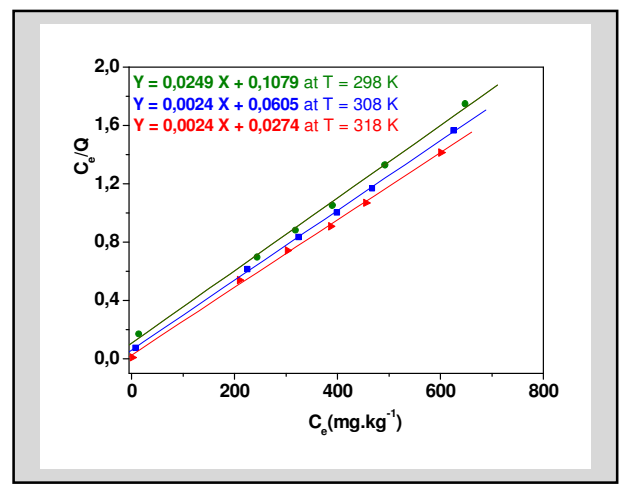

Fig. 9. Langmuir linear plot at $298 \mathrm{~K}, 308 \mathrm{~K}$ and $318 \mathrm{~K}$. form:

The experimental results were also analyzed using the Freundlich equation, which has the general $\ln (Q)=\ln \left(K_{f}\right)+1 / n \ln \left(C_{e}\right)$

where $\mathrm{Q}$ is the amount of polymer adsorbed per unit mass $\left(\mathrm{mg}_{\mathrm{g}} \mathrm{g}^{-1}\right), \mathrm{C}_{\mathrm{e}}=$ the concentration of adsorbate at equilibrium (mg. $\left.\mathrm{kg}^{-1}\right) . \mathrm{K}_{\mathrm{f}}$ and $\mathrm{n}$ are Freundlich constants. (Fig.10 and Table 3).

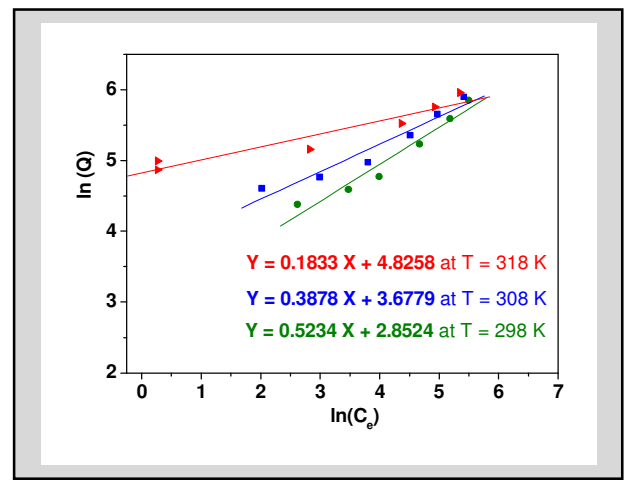

Fig. 10. Freundlich linear plot at $298 \mathrm{~K}, 308 \mathrm{~K}$ and $318 \mathrm{~K}$.

Table 3. Parameters of Freundlich and Langmuir analysis of the isotherms at three temperatures

\begin{tabular}{|c|c|c|c|c|c|c|}
\hline \multicolumn{4}{|c|}{ Langmuir constants } & \multicolumn{3}{c|}{ Freundlich constants } \\
\hline $\mathrm{T}(\mathrm{K})$ & $\mathrm{Q}_{0}$ & $\ln \left(\mathrm{K}_{\mathrm{L}}\right)$ & $\mathrm{R}^{2}$ & $\mathrm{~K}_{\mathrm{F}}$ & $1 / \mathrm{n}$ & $\mathrm{R}^{2}$ \\
\hline 298 & 401 & 13,85 & 0,99 & $1,3.10^{-3}$ & 0,52 & 0,95 \\
\hline 308 & 418 & 16,70 & 0,99 & $1,9.10^{-4}$ & 0,38 & 0,96 \\
\hline 318 & 433 & 17,45 & 0,99 & $1,06.10^{-5}$ & 0,18 & 0,97 \\
\hline
\end{tabular}


On table 3 are also reported the correlation coefficient $\left(\mathrm{R}^{2}\right)$ corresponding to the fit. Based on these values, we can consider that the adsorption isotherms follow the model of Langmuir.

\subsection{Estimation of thermodynamic parameters of the model of Langmuir}

Three parameters can then be deduced: the standard adsorption enthalpy $\left(\Delta \mathrm{H}^{\circ}\right)$, the standard Gibbs energy of adsorption $\left(\mathrm{AG}^{\circ}\right)$ and the standard entropy of adsorption $\left(\Delta \mathrm{S}^{\circ}\right)$ for the mechanism of adsorption of chitosan on activated carbon Norit SUPRA EUR. The following equations describe the calculation.

$$
\begin{gathered}
\Delta G^{\circ}=-R T \times \ln K_{L} \\
\Delta G^{\circ}=\Delta H^{\circ}-T \Delta S^{\circ}
\end{gathered}
$$

Where $\mathrm{T}$ is the absolute temperature in Kelvin, $\mathrm{R}$ is the ideal gas constant $\left(8.314 \mathrm{~J} \cdot \mathrm{mol}^{-1} \cdot \mathrm{K}^{-1}\right)$ and $\mathrm{K}_{\mathrm{L}}$ is the equilibrium constant of adsorption. The equations (E6) and (E7) can be rewritten as follows:

$$
\ln K_{L}=\Delta S^{\circ} / R-\Delta H^{\circ} / R T
$$

The plot of $\ln K_{L}$ versus $1 / T$ is a straight line of slope $\left(-\Delta H^{\circ} / R\right)$ which gives also $\Delta S^{\circ} / R$ (Fig.11).

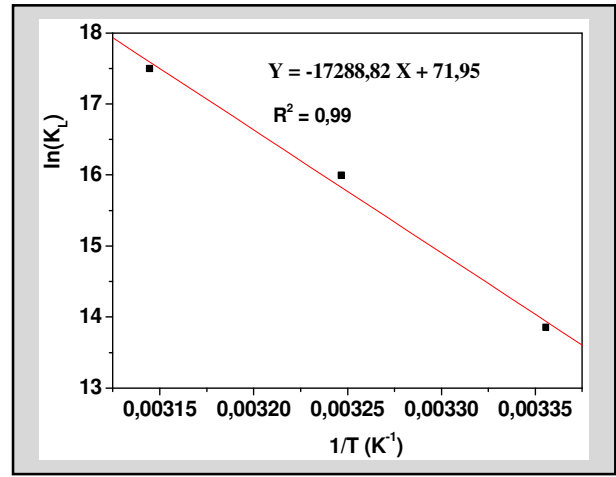

Fig. 11. Graphical representation of equation: $\ln \left(K_{L}\right)=f(1 / T)$.

The $\Delta \mathrm{H}^{\circ}, \Delta \mathrm{S}^{\circ}$ and $\Delta \mathrm{G}^{\circ}$ obtained from $\left(\ln \mathrm{K}_{\mathrm{L}}=\mathrm{f}(1 / \mathrm{T})\right)$ are given in Table 4 .

Table 4. Thermodynamic parameters of adsorption

\begin{tabular}{|c|c|c|c|}
\hline $\mathbf{T}\left({ }^{\circ} \mathbf{K}\right)$ & $\mathbf{\Delta H}^{\circ}\left(\mathbf{k J} \cdot \mathbf{m o l}{ }^{\mathbf{1}}\right)$ & $\boldsymbol{\Delta S}^{\circ}\left(\mathbf{k J} \cdot \mathbf{m o l}^{\mathbf{1}} \cdot \mathbf{K}^{\mathbf{1}}\right)$ & $\boldsymbol{\Delta G}^{\circ}\left(\mathbf{k J} \cdot \mathbf{m o l}{ }^{\mathbf{1}}\right)$ \\
\hline 298 & 143,73 & 0,598 & $-34,46$ \\
\hline 308 & 143,73 & 0,598 & $-40,45$ \\
\hline 318 & 143,73 & 0,598 & $-46,25$ \\
\hline
\end{tabular}

The adsorption of chitosan molecules on the surface of the active carbon is accompanied by a reorganisation of both solvent and polymer molecules, which results in an endothermic heat. The positive values of entropy $\left(\Delta \mathrm{S}^{\circ}\right)$ indicate an increase in disorder at the interface solid / solution during the adsorption.

\section{Conclusions}

This study is an experimental approach of the selection of components of composite materials in the form of films, which can be used as a healing under dressings. Through a study of some 
physicochemical characteristics of precursor materials on the one hand, and the study of the adsorption interaction between chitosan and activated carbon on the other hand, a couple composed of an activated carbon Norit A or B SUPRA EUR and chitosan batch-112 has been proved to be promising. The activated carbon Norit A SUPRA EUR is not very different from the other sample. It has a large surface area and a good adsorption capacity of chitosan and then can be considered as a good choice. The sterilization of this activated carbon Norit A SUPRA EUR does not have important effect on the porous structure, the surface area or the maximum adsorption capacity, which appears as an excellent point. Chitosan batch-112 has a larger affinity with AC compared to the chitosan batch-111. This is related to the chemical structure of chitosan: the affinity with negative surface sites decreases when the degree of acetylation increases. At $\mathrm{pH} 4$, the amine groups become $\mathrm{NH}_{3}{ }^{+}$. Therefore chitosan batch-112, which is characterized by the presence of a great quantity of $\mathrm{NH} 2$ groups can strongly adsorb on negative sites on the surface of activated carbon. The thermodynamic characteristics of such adsorption have been quantified using the temperature variation of adsorption.

\section{References}

1. T. Kean, M. Thanou, Advanced Drug Delivery Reviews 62, 3 (2010).

2. E.I Rabea, E.T.B. Mohamed, C.V. Stevens, G. Smagghe, W. Steurbaut, Biomacromolecules 4, 1457 (2003).

3. K.W. Kim, R.L. Thomas, Food Chemistry 101, 308 (2007).

4. R. A. A. Muzzarelli, C. Muzzarelli, Chitosan chemistry: relevance to the biomedical sciences in: Polysaccharides I. Structure, Charactérization and use. Springer Berlin Adv. Polym. Sci 186, $151(2005)$.

5. L. Illum, J. Pharm. Sci. 96, 473 (2007).

6. Y. Fukumori, H. Ichikawa, Adv. Powder Technol. 17, 1 (2006).

7. M. Thanou, H. F. Junginer, Pharmaceutical applications of chitosan and derivatives in: Polysaccharides. Dumitriu S. ed., New York: Marcel $2^{\text {end }}$ (2005) 661.

8. M. Parbaharan, J. F. Mano, Drug delivery 12, 41 (2005).

9. Y. Kato, H. Onishi, Y. Machida, Biomaterials 25, 907 (2004).

10. M. N. V. Ravi Kumar, R. A. A. Muzzarelli, C. Muzarelli, H. Sashiwa, A. J. Domb, Chem. Rev. 104, 6017 (2004).

11. H. Sashiwa, S. I. Aiba, Prog. Polym. Sci. 29, 887 (2004).

12. J. Berger, M. Reist, J. M. Mayer, O. Felt, R. Gurny, Eur. J. Pharm. and Biopharm. 57, 35 (2004).

13. C. Shi, Y. Zhu, X. Ran, M. Wang, Y. Su, T. Cheng, J. Surgical Research 133, 185 (2006).

14. M. H. Struszczyk. Polimery 47, 396 (2002).

15. M. N.V. Ravi Kumar, A review of chitin and chitosan applications, React. Funct. Polym. 46, 1 (2000).

16. W. Wei, G. H. Ma, L. Y. Wang, J. Wu, Z. G. Su, Acta Biomaterialia 6, 205 (2010).

17. S. J. Lee, K. Park, Y. K. Oh, S. H. Kwon, S. Her, I. S. Kim, K. Choi, S. J. Lee, H. Kim, S. G. Lee, K. Kim, I. C. Kwon, Biomaterials 30, 2929 (2009).

18. M. Fuente, M Ravina, P. Paolicelli, A. Sanchez, B. Seijo, M.J. Alonso, Advanced Drug Delivery Reviews 62, 100 (2010).

19. G. M. William., J. Q. Herbert., Method of achieving homeostasis inhibiting fibroplasias, and promoting tissue regeneration in a tissue wound. (United States Patent No. 4532134, 1985).

20. C. Chatelet, O. Damour, A. Domard., Biomaterials 22, 261 (2001).

21. M. Rinaudo, A. Domard, Solution properties of chitosan. In: G. Skjak-Braek, T. Anthonsen, P. Sandford, Editors, Chitin and chitosan. Sources, chemistry, biochemistry, physical properties and applications, Elsevier, London and New York (1989) pp. 71-86.

22. P. R. Austin, Chitin solvents and solubility parameters in: Chitin and Chitosan and related enzymes. Zikakis J. P, ed., Orlando: Academic Press (1984) p. 227.

23. P. Sorlier, A. Denuziere, C. Viton, A. Domard, Biomacromolecules 2, 765 (2001). 
24. J. Zajac, R. Dutartre, D. J. Jones, J. Roziere, Thermochimica Acta 379 (2001) 123 -130.

25. T. Ito, L.C de Menorval, E. Guerrier, J. P. Fraissard, Chem . Phys. Lett., 111, 271 - 274 (1984). 